\title{
Prospects for Sino-Turkish Relations
}

\author{
Unlikely Partnership or Uncertain \\ Complex?
}

Pan Honghui

\begin{abstract}
This article addresses the major opportunities and challenges facing Sino-Turkish relations, an important relationship often neglected by scholars and practitioners of international relations. While identifying the two dominant challenges facing the two ancient civilizations, i.e. the Xinjiang Uighur issue and unbalanced trade favoring China, this article maintains that the two countries enjoy vast room for cooperation both economically and geopolitically. Their cooperation in China's Xinjiang Uighur Autonomous Region can also result in a win-win situation, with Turkey making better use of its psychological linkage to the local Uighurs to increase its investment in infrastructure and China winning more Uighur identification with the central government by enhancing the local economy and living standards. In the international arena, though a comprehensive partnership of security cooperation has yet to develop, both countries have been engaged in ever closer cooperation as evidenced by Turkey's intensifying efforts to join the Chinese-led Shanghai Cooperation
\end{abstract}

Pan Honghui is Researcher at the Faculty of Psychology and Educational Sciences, Vrije Universiteit Brussel. Her address is Room 3B241, Pleinlaan 2, 1050 Brussels, Belgium. She can also be reached at phonghui@vub.ac.be.

The author would like to thank Prof. Şuhnaz Yılmaz Özbă̆cı for his invaluable help during the author's writing of this article as a researcher at Koç University, Turkey in 2014.

(c) 2016 World Century Publishing Corporation and Shanghai Institutes for International Studies China Quarterly of International Strategic Studies, Vol. 2, No. 1, 101-117

DOI: $10.1142 / S 237774001650007 X$ 
Organization and Chinese companies' active participation in Turkey's many military projects. Nevertheless, given the relatively small size of the Turkish economy and its decades-long dependence on Western powers in security, economic, and cultural terms, the future Sino-Turkish relationship will remain largely a function of their respective relations with the West.

Keywords: Sino-Turkish relations; Xinjiang Uighur issue; trade imbalance; win-win cooperation.

\section{An Important Yet Often Neglected Relationship}

Only a few years ago, Sino-Turkish relations were deemed by many Western scholars to neither have much strategic significance nor huge potential for lasting development. However, after China's limited participation in the Turkey-initiated air force exercise "Anatolian Eagle" in October 2010, the first-ever joint military training between China and a NATO member, a lot of concerns have emerged over whether Turkey is shifting its military and diplomatic focus to the East. Not only are NATO members, especially the United States, cautious of China's growing prestige and stronger military posture due to such participation, but the United States has also strongly objected to the inclusion of F-16 fighters by Turkey in the training lest any key technological information be leaked to the Chinese. Such concerns have aroused more and more studies from international academia as well as strategic analysts with regard to the future trends of Sino-Turkish relations.

Some analysts note the many challenges in Sino-Turkish relations and thus believe that the two countries can hardly develop a true-sense strategic partnership for such reasons as their ideological/religious discrepancy, the Xinjiang Uighur issue, their different stances on the Syrian civil war, and unbalanced trade. ${ }^{1}$ They argue that the ethnic issue in China's Xinjiang Uighur Autonomous Region constitutes an obstacle impossible to overcome in Sino-Turkish relations, for Turkey seems always prepared to risk a serious breach of its political and economic ties with China for the sake of promoting its pan-Turkic/Islamic brand. Other analysts, however, tend to

\footnotetext{
${ }^{1}$ See, for example, Karen Kaya, "Turkey and China: Unlikely Strategic Partners," Operational Environment Watch, May 17, 2013, http://fmso.leavenworth.army.mil/documents/ Turkey-and-China.pdf.
} 
emphasize the ever stronger driving forces behind the bilateral relationship, among which are the close historical ties between the two ancient civilizations and their vast shared interests in ever expanding areas.

Caught between the two diverse views, one would reasonably wonder: is the Sino-Turkish relationship doomed to be an unlikely partnership or can it be upgraded beyond the current challenges? This article adopts a two-level analysis, focusing on domestic factors as well as international factors, and examines both the close historical ties and ongoing cooperation between both sides, so as to offer a more comprehensive and balanced picture of this often ignored important bilateral relationship.

This article is divided into five sections. First, it presents a historical account of Sino-Turkish relations with a traceable record dating back to 150 BC. Second, it discusses the Xinjiang Uighur issue, admittedly the biggest obstacle to stronger Sino-Turkish ties, while highlighting their converging interests in combating separatism and terrorism. Third, it explores the bilateral economic relations and identifies potential areas for their joint efforts to adjust the huge trade imbalance. Fourth, it addresses the trends of SinoTurkish political-security relations, an issue of potential geopolitical significance especially to the West. Finally, it discusses the possible trends of future Sino-Turkish relations.

\section{A Brief History of Sino-Turkish Relations}

China and Turkey are located at both ends of the vast Asian continent. China occupies eastern Asia while the majority of Turkey covers western Asia, with about 3 percent of its total land called Thrace in Europe. The Silk Road initiated by Zhang Qian during China's Han dynasty (around 130 BC) started from Chang'an, Han's capital, to the Roman Empire, passing through today's Chinese Xinjiang to Anxi (the name for Ancient Iran) and Tiaoshi (today's Arabian Peninsula), and then arriving at its destination, the Roman Empire. ${ }^{2}$

The Silk Road served as a bridge between the ancient East and West in both economic and cultural terms. Through this channel, China was able to export its silk, tea, and porcelain products to Constantinople, which later

2“Turkish-Chinese Relations in History,” Chinese-Turkish Foundation, http://www. turkcindostlukvakfi.org.tr/en/menu-sayfa.php?id=14. 
became treasures of the Ottoman Empire Palace. Today, Topkapi Palace Museum of Turkey has a collection of more than twenty thousand pieces of porcelain from many Chinese dynasties, which are witnesses of the frequent exchange between China and Turkey over the past centuries.

Modern development of the diplomatic relationship between China and Turkey has been influenced greatly by international political dynamics, especially the U.S. stance toward China and the domestic environments of both countries. In 1934, Turkey and then Republic of China established diplomatic relations. To extend Chinese friendship, Chiang Kai-shek, then President of the Republic, sent his own photo in uniform with his signature to Kemal Ataturk, Turkey's founding father, as a personal gift, which can be found today in the Museum of Kemal Ataturk in Ankara. ${ }^{3}$ Later, during the Korean War from June 1950 to July 1953, Turkey as a pending NATO member (Turkey joined the NATO in 1952) sent an army of about 5,000 troops to join the U.S.-led united force against North Korea and the newly founded People's Republic of China (PRC). It was not until 1971 did Turkey choose to establish diplomatic relationship with the People's Republic of China, against the backdrop of potential rapprochement between the United States and the PRC.

This wartime experience shaped the mutual perceptions of Turkey and China. On one hand, Turkey under the leadership of Adnan Menderes in the 1950s was viewed by China as a "running dog" and puppet of imperial powers; on the other hand, China was seen as a naïve believer of communism, and its soldiers were depicted as either evil or pitiful in many Turkish written records. Such narratives and images have endured in the minds of many in both countries even till today. ${ }^{4}$

Despite their close historical ties, China and Turkey did not have much contact at modern times until they established formal diplomatic ties in 1971.

${ }^{3}$ Xiao Jing, “Goujian zhongguo yu tuerqi xinxing zhanlue hezuo guanxi [Establishing a New Strategic Cooperative Relationship between China and Turkey]," West Asia and Africa, Vol. 9 (2011).

${ }^{4}$ Editorial, "Beijing, shanghai, tianjing, wuhan, guangzhou deng shijige chengshi renmin shengda jihui, jianjue zhichi tuerqi renmin de aiguo zhengyi douzheng [Citizens in More than Ten Major Cities in Great Rallies to Voice Resolute Support for Turkish People's Patriotic]," People's Daily, May 5, 1960. 
Sino-Turkish relations, especially in the political arena, began to improve rapidly after both countries established formal diplomatic ties on August 4, 1971. Not only were there a growing number of mutual highlevel visits (see Table 1), but they also supported each other in a wide range of international and domestic political affairs. For example, while the Western community condemned China for the Tiananmen incident in 1989, Turkey maintained that it was China's domestic affair that others should not interfere with; in return, China remained neutral on the Cyprus and Kurdish issues, which were on top of Turkey's trouble agenda. Needless to say, their common stance in fending off Soviet aggression was another driver behind their ever more intense political exchanges and communication during the Cold War.

Table 1. Bilateral Head-of-State Visits Between China and Turkey (1982-2015).

\begin{tabular}{ll}
\hline Year & Turkish Visits to China \\
\hline 1982 & Kenan Evren, President \\
1995 & Süleyman Demirel, President \\
1998 & Bülent Ecevit, Prime Minister \\
2003 & Recep Tayyip Erdoğan, Prime Minister \\
2014 & Abdullah Gül, President \\
2015 & Recep Tayyip Erdoğan, President \\
\hline & Chinese Visits to Turkey \\
\hline 1984 & Li Xiannian, President \\
2000 & Jiang Zemin, President \\
2002 & Zhu Rongji, Premier \\
2012 & Xi Jinping, then Vice President \\
\hline
\end{tabular}

Since the end of the Cold War, Sino-Turkish relations have achieved much more progress apart from mutual political support. A number of agreements have been signed to enhance economic, cultural, and people-topeople exchanges, and their bilateral trade has increased from less than US $\$ 1$ billion in the 1990s to over US $\$ 27.7$ billion in 2014 . Yet their biggest common interest still lies in the political and security fields, as they are both faced with the grave challenges of the "three evil forces (terrorism, separatism, and religious radicalism)" in Central Asia, coupled with protracted turmoil in the Middle East. 
To sum up, while ideological differences and negative historical images continue to be a barrier to communication and cooperation between the two ancient civilizations, China and Turkey have been achieving continuing progress in their relationship, based on their common interest in expanding trade and maintaining stability in Central Asia and the Middle East. At the same time, the bilateral relationship is facing a lot of challenges as well, the most salient of which are the Xinjiang Uighur issue and their unbalanced trade. Nevertheless, in the two major challenges also lie new opportunities for cooperation between both countries to enhance their relationship.

\section{The Xinjiang Uighur Conundrum}

China is a nation made up of 56 ethnic groups with the majority (91.6 percent) being Han and the remaining 55 constituting roughly 8.4 percent of the total population..$^{5}$ Xinjiang is an autonomous region in western China, in which reside the majority of China's 10 million Uighurs, widely believed to be the brethren of Turks; many of them are Muslims and speak a variant of the Turkish language. It is home to a separatist movement seeking to found a so-called "East Turkestan," in part encouraged by Turkey's occasional ambition to expand its influence as an emerging regional power by strengthening its ethnic and religious ties in its immediate neighborhood.

A tragic riot happened in Urumqi, capital of the Xinjiang Autonomous Region in July 2009, reportedly triggered by separatists making use of the incongruity between the Han people and local Uighurs. According to Chinese official statistics, the riot claimed at least 300 deaths and 1,721 injuries on July 5 alone. The Chinese government condemned it as "a schemed violent riot organized by separatists overseas" and held Rebiya Kadeer, the leader of World Uighur Congress (WUC), to full responsibility of fanning the riot, while Kadeer denied the charge and argued that the protesters were unsatisfied with the policy adopted by the

5“The World Factbook," CIA, https://www.cia.gov/library/publications/the-worldfactbook/geos/ch.html. 
Chinese government toward the Uighurs. She fired back that the Uighur masses were only engaged in a peaceful demonstration when they were suddenly shot at by armed police, and that the Han people had also attacked thousands of Uighurs in Shaoguan, Guangdong Province a week before. The riot soon caused a crisis for the Sino-Turkish political relationship after Turkish Prime Minister Recep Tayyip Erdoğan, leader of the Islamist-rooted Justice and Development Party (AKP), openly criticized the Chinese central government's policy toward Xinjiang and even referred to the government's efforts to bring back social order as an act of "genocide."

An editorial of China Daily, China's central English language newspaper, urged Erdoğan to take back his remarks not only because they were "ill-founded" but also because they were against the basic principle of SinoTurkish relations on non-interference in each other's domestic affairs. In a telephone conversation with his Turkish counterpart on July 12, 2009, then Chinese Foreign Minister Yang Jiechi maintained that the prevailing "three evil forces" - separatism, terrorism, and religious extremism - were the ultimate cause of unrest in Xinjiang. ${ }^{6}$

Erdoğan's reckless remarks and China's furious reaction in July 2009 were interpreted by many as the beginning of a downgrade of Sino-Turkish relations due to the seemingly insurmountable Xinjiang Uighur issue. Yet such interpretation has largely missed the point. Leaving aside the generally restrained public tone of the Turkish government on the riot, Erdoğan's speech itself was by and large a response to domestic political pressure rather than a showcase of his support for the Uighur movement, for the Turkish public and a few strong interest groups, under the influence of the large Uighur community in Turkey, were mounting pressure on him to condemn the Chinese government and support their presumed brethren. In fact, immediately after he gave those sharp remarks, Erdoğan sent a special envoy to China to convey his strong commitment to furthering

6"Yang Jiechi tong tuerqi waizhai tonghua, tufang cheng buganshe zhongguo neizheng [Turkish Foreign Minister Confirms Non-Interference in China's Domestic Affairs in Call with Yang Jiechi]," China News, July 13, 2009, http://www.chinanews.com/gn/news/2009/ 07-13/1773556.shtml. 
diplomatic and economic ties with China despite the unfavorable public opinion on both sides. ${ }^{7}$

Certainly, many Turkish people have never given up a pan-Turkic dream to regain all territories ever held by Turks. For example, since 1925 the Turkish presidential seal has had a big star at the center surrounded by 16 smaller stars, symbolizing the 16 Turkish empires in history, some of which occupied the bulk of today's Xinjiang. After the collapse of the Soviet Union, such an ambition once again found a bigger market among the Turkish public due to the U.S. advocacy for the Turkish economic model in Central Asia. In reality, however, a

Turkish leaders' occasional harsh remarks on China's policy in Xinjiang are more a result of domestic political pressure than an effort to achieve any pan-Turkic ambition. pan-Turkic agenda has proven completely unrealistic both because it would cause serious problems for Turkey's relationship with neighboring nations, especially Russia and China, and because Turkey lacks the basic resources to promote it even through people-to-people exchange, confined by the poor condition of infrastructure like roads and railways connecting Turkey with surrounding regions. ${ }^{8}$

Having realized these challenges and limitations, the Turkish government has long adopted a more realistic approach in its relationship with China. The first indicators were President Suleyman Demirel's visit to China in 1995 and his reportedly "secret order" that no civil servants were to participate in organizations or meetings initiated by the Uighur offspring in Turkey and that some Uighur political dissents should be expelled from Turkey. ${ }^{9}$ Furthermore, consensus was reached in 2005

${ }^{7}$ Wang Dong, “Tuerqi teshi jiu wulumuqi shijian fangwen zhongguo [Turkish Envoy Visited China over Urumqi Incident]," Vision Times, September 2, 2009, http://m.secretchina.com/ node/308599.

${ }^{8}$ Sener Akturk, "Turkish Russian Relations after the Cold War (1992-2002)," Turkish Studies, Vol. 7, No. 3 (2006), pp. 337-364.

${ }^{9} \mathrm{Ma}$ Dazheng and $\mathrm{Xu}$ Jianying, Dongtujue sitanguo mimeng de huanmie [The Busted Dream of East Turkistan] (Urumqi: Xinjiang People's Press, 2006), p. 173. 
between Turkey's Gendarmerie General Command and its Chinese counterpart on strengthening their cooperation in maintaining social stability, combating crime, and counterterrorism.

Since then all summit meetings between both countries have had the Xinjiang Uighur issue on the agenda, making it a new land of opportunities for enhanced bilateral cooperation. Indeed, both countries have been working more closely in mainly two areas concerning the Xinjiang region over the past few years.

One is growing economic cooperation in the region. As then Chinese Vice President Xi Jinping proposed on his visit to Turkey in February 2012, China would be more open to Turkish business investors who, in turn, may take advantage of their cultural and psychological links with local Uighurs in infrastructure building in Xinjiang. China's rationale is that by improving the living standards of local Uighurs, the central government can win more Uighur identification with the mainstream Chinese culture and the Chinese nationality. Yet the prerequisite is that China has to be convinced that Turkey has given up its pan-Turkic ambition about Xinjiang, and that its economic involvement in the region will enhance local prosperity instead of spurring new separatist momentum.

The other area is counterterrorism along the New Silk Road. Party in an effort to promote diversification of its energy supplies so as to lower its dependence on oil imports over sea routes easily subject to piracy or major power controls, China is going all out to build a New Silk Road through Xinjiang and passing by Central Asian regions. ${ }^{10}$ However, such an effort carries with it many risks. The region is under constant threat of religious extremism, and there have been an increasing number of terrorist attacks in this area since the riot in Urumqi in July 2009. During 2013 and 2014 alone Xinjiang separatists launched four major terrorist attacks in different Chinese cities, which claimed 79 lives in total (see Table 2). In response, a State Counterterrorism Leading Group was established under the new Chinese leadership in 2013 to strengthen and coordinate national counterterrorist measures.

\footnotetext{
${ }^{10}$ Keith Johnson, "Rough Ride on the Silk Road," Foreign Policy, May 1, 2014, http:// foreignpolicy.com/2014/05/01/rough-ride-on-the-new-silk-road/.
} 
Table 2. Casualties of Major Terrorist Attacks by Uighur Separatists (2013-2014).

\begin{tabular}{lll}
\hline Time & Place & \multicolumn{1}{c}{ Casualties } \\
\hline October 31, 2013 & Beijing & 8 deaths \\
March 31, 2014 & Kunming & 29 deaths; 143 injuries \\
April 30, 2014 & Urumqi & 3 deaths; 4 injuries \\
May 22, 2014 & Urumqi & 39 deaths; 94 injuries \\
\hline
\end{tabular}

Turkey is also mired in its own combat against Islamic extremist/terrorist activities and the armed Kurdish opposing forces. That makes it possible for China and Turkey to enhance information sharing and cooperation in other fields. For example, China, as one of the five permanent members of the UN Security Council, may support Turkey on the Cyprus and Kurdish issues in the international arena; in reciprocity, Turkey may do more to contain Uighur separatist forces in Turkey and work with China in cross-border information control.

\section{Huge Potential for Bilateral Economic Cooperation}

Over the past two decades, Sino-Turkish trade relations have been developing rapidly — yet in an imbalanced way. By 2013 China had become the second-largest source of imports for Turkey, only after Russia, while Turkey remained an insignificant partner for China whether in the importing or exporting sector. Despite the wishful joke told by Turkish President Kenan Evran in the 1980s that "If every one of the Chinese people can buy an orange from Turkey, then we can be rich," China has enjoyed growing trade surplus with Turkey since the mid-1990s. Chinese exports to Turkey were US $\$ 431$ million in 1995 out of their total trade volume of $\$ 575$ million. ${ }^{11} \mathrm{In}$ 2010, the bilateral trade increased to about $\$ 15.7$ billion with Chinese exports to Turkey being $\$ 13.9$ billion, almost seven times more than Turkish

${ }^{11}$ Yitzhak Shichor, "Ethno-Diplomacy: the Uyghur Hitch in Sino-Turkish Relations," East-West Center Policy Studies No. 53 (Honolulu: East-West Center, 2009), p. 38, http:// www.eastwestcenter.org/fileadmin/stored/pdfs/ps053.pdf. 
exports to China. ${ }^{12}$ Their trade imbalance further increased to nearly $\$ 22$ billion in $2014 .{ }^{13}$

The ultimate cause of the huge trade imbalance between China and Turkey lies in their incompatible trade structure. China and Turkey are both strong at labor-intensive industries, such as manufacturing of textile and leather goods, and they compete intensely on the European market, with Chinese goods being cheaper. While ordinary Turkish people prefer cheap Chinese commodities from textile products to electric appliances due to their limited purchasing power, China mainly imports raw minerals and chemical products from Turkey, usually with low added value and totally subject to the slowing dynamics of the Chinese manufacturing industries.

However, one should not draw a hasty conclusion about future SinoTurkish economic cooperation simply based on the huge amount of Turkish trade deficits. There is in fact much potential for development of the bilateral economic relations.

First, regardless of the huge trade imbalance, the total trade volume between both countries has been growing from $\$ 575$ million in 1995 to $\$ 27.74$ billion in 2014 , a nearly 50 times' growth that greatly benefits industries and consumers in both countries.

Sino-Turkish trade imbalance is likely to be reduced with their closer cooperation on the "Belt and Road" Initiatives and more Chinese tourists to Turkey.

Second, more and more cooperation is taking place between both countries in tertiary industries, or service sectors, rather than in the lower-end manufacturing sectors, as a result of their upgraded economic structures. According to statistics, the output of the service sector in China's total GDP grew from 11.9 percent in 1970 to 28.2 percent in 2012, while the output of primary industry decreased from 35.3 percent to little more than 10 percent (see Table 3). This

${ }^{12}$ See statistics on the website of the Economic and Commercial Counselor's Office of the Chinese Embassy in Turkey, http://tr.mofcom.gov.cn/article/jmxw/201012/ 20101207279272.html, 2010-12-20.

13 "Erling yisi nian tuerqi yu zhongguo de chuangbian maoyie wei 227.4 yi meiyuan [Bilateral Trade between Turkey and China in 2014 Reached \$27.74 Billion]," China Business Information, May 6, 2015, http://www.askci.com/news/2015/05/06/93644qfvd.shtml. 
Table 3. Upgrade of China's Economic Structure (1970-2012).

\begin{tabular}{ccccccc}
\hline Year & Agriculture & Manufacturing & Construction & Trade & Transport & Service \\
\hline 1970 & 35.3 & 36.5 & 3.7 & 7.3 & 5.2 & 11.9 \\
1980 & 30.2 & 43.9 & 4.3 & 5.3 & 4.7 & 11.6 \\
1990 & 26.8 & 36.7 & 4.4 & 8.9 & 6.6 & 16.6 \\
2000 & 15.1 & 40.4 & 5.6 & 10.4 & 6.2 & 22.4 \\
2010 & 10.1 & 40 & 6.6 & 10.9 & 4.8 & 27.6 \\
2012 & 10.1 & 38.5 & 6.8 & 11.5 & 4.8 & 28.2 \\
\hline
\end{tabular}

Note: Percentage in total GDP.

Source: Compiled by the author from Macroeconomics in China. ${ }^{15}$

means that there is a growing Chinese market for banking, tourism, and other services of which Turkey can strive for a bigger share. My personal experience a few years ago serves as an example. Upon my arrival in Turkey, I was surprised to find that the local Garanti Bank offered Chinese language services on all ATMs, and they worked closely with the Union Pay, China's biggest banking association, to provide renminbi (RMB) services to Chinese citizens in Turkey. For another example, the number of Chinese tourists bound for Turkey has increased rapidly in recent years from 114,600 in 2012 to nearly 300,000 in 2015 - thanks to Turkey's efforts to facilitate visa application and its marketing activities during the Turkish Cultural Year of 2013 in China. ${ }^{14}$ Still, considering the more than 100 million overseas visits by Chinese mainland tourists each year, there are certainly a lot of opportunities for the Turkish tourist market.

Third, the trade imbalance between China and Turkey is likely to be mended in the future especially because of China's growing strategic needs for Turkey's support in the Xinjiang Uighur issue and the promotion of its "Belt and Road" Initiatives. As suggested by Chen Deming, Minister of Commerce of China, on his visit to Turkey in January 2010, China is committed to enhancing relations with Turkey mainly by four means: (1) to

14"Zhongguo fu tuerqi luyou renshu zengzang xunsu [Number of Chinese Tourists to Turkey Increases Rapidly]," China Tourism Information, February 21, 2014, http://news.cthy. com/Allnews/16689.html; and "Erlingyiwu nian fu tuerqi chujing you tongbi shangzhang 100\% [Number of Chinese Tourists to Turkey to Double in 2015]," Beijing Youth Travel Service, July 17, 2015, http://www.99ly.com.cn/news/8563.html.

${ }^{15}$ Statistics obtained from: http://kushnirs.org/macroeconomics/profile/profile_china. html\#str1. 
further open Chinese markets to Turkish enterprises and goods for more balanced trade; (2) to explore new areas for cooperation such as in investment, banking, telecommunications, and new energy; (3) to encourage Turkish enterprises to participate in the developmental agenda of West China; and (4) to settle trade disputes through friendly consultation and work together to expand their market share in other countries. ${ }^{16}$ Thus it is hopeful that China will give more preferential treatment to Turkish investors and merchants in exchange for Turkey's cooperation in the "Belt and Road" Initiatives as well as in counterterrorism and anti-separatism in Xinjiang.

Therefore, the widely held assumption that trade imbalance between China and Turkey will remain a major obstacle in their bilateral relations is largely a short-sighted stereotype. The changing economic structures of both countries, China's growing need for Turkish support and participation in its domestic and international economic initiatives, as well as the stronger purchasing power of Chinese citizens, all provide increasing momentum for closer economic ties between them.

\section{Mutual Need for Geopolitical Cooperation}

When exploring the future Sino-Turkish relationship, Karen Kaya, an analyst at Turkey's Foreign Military Studies Office (FMSO), holds that it is very unlikely for them to become strategic partners. She argues that other than differences in ideology and religious beliefs, the Xinjiang Uighur issue and their conflicting stances on the Syrian civil war - China opposes any military intervention on the ground that it is Syria's domestic affair, while Turkey tends to support the opposition and condemns the Assad regime will seriously hinder strategic cooperation of both countries in the international arena. Besides, Turkey has to overcome tremendous pressure from other NATO members in promoting security relations with China. ${ }^{17}$

16“Chen Deming zhuanwen chanshu zhongfang dui fazhan zhongtu jingmao hezuo jiji lichang [Chen Deming on China's Positive View of Developing Sino-Turkish Economic and Trade Cooperation]," Central People's Government of China, January 7, 2010, http://www.gov.cn/ gzdt/2010-01/07/content_1504936.htm.

${ }^{17}$ Kaya, "Turkey and China: Unlikely Strategic Partners." 
Nevertheless, there are growing needs in both countries for each other's strategic support and cooperation in the international arena. For China, the major goal is to strengthen security relations with Turkey as a NATO member in order to foster a closer security partnership with the traditional Western alliance for more geopolitical balance in Eurasia; for Turkey, strategic cooperation with China may provide extra leverage in enhancing its regional status and its further integration into the EU.

A notable example of Sino-Turkish security cooperation is China's joining in the "Anatolian Eagle" air force exercise at Turkey's invitation in October 2010. This happened against the backdrop of growing Western pressure on Turkey for its reserved participation in sanctions against Iran, as well as the deteriorating bilateral relationship between Turkey and Israel after the "Gaza flotilla raid" in May 2010, in which nine Turkish citizens were killed during an Israeli raid on a Turkish flotilla carrying humanitarian aid to the Gaza Strip. Although China sent only four aircrafts to join in the exercise, it was the first time for the Chinese air force to participate in a joint military exercise with a NATO member, thereby enhancing China's military posture in the Near East. Turkey, through joint military exercise with China, also conveyed its disgruntlement about the Western pressure in a subtle yet unyielding way.

Another example is China Precision Machinery Export-Import Corporation's (CPMEIC) bidding to jointly develop the HQ-9 surface-to-air missile defense system with Turkey. Despite the huge pressure from the United States and major EU countries, Turkey decided to accept CPMEIC's offer in 2013, for it was at least US\$ 1 billion cheaper than those of other countries including the United States, France, and Russia; China also agreed to transfer relevant technologies and invest in the construction of a high-technology zone in Istanbul. Although Turkey had to withdraw from the deal and reopen bidding in 2014 under the Western accusation that it might leak key technical information about the NATO's air and missile defense system, ${ }^{18}$ its initial decision to cooperate with a Chinese militaryprone company serves as clear evidence of the growing potential of

${ }^{18}$ Denise Der, “Why Turkey May Not Buy Chinese Missile Systems After All," The Diplomat, May 7, 2014, http://thediplomat.com/2014/05/why-turkey-may-not-buy-chinesemissile-systems-after-all/. 
Sino-Turkish cooperation in security arenas. At least, Turkey's initial acceptance of the Chinese offer indicates that China enjoys great global competitiveness in both price and technology in developing long-range missile defense systems.

\section{To promote its} international status, Turkey is expected to seek to join the EU and the China-led SCO at the same time.
China and Turkey have also begun to cooperate on other geopolitical issues. Disillusioned by Turkey's failure to be accepted into the EU despite its decades-long efforts, the Turkish leadership has demonstrated increasing interest in joining the China-led Shanghai Cooperation Organization (SCO), as exemplified in then Turkish Prime Minister Recep Tayyip Erdoğan's explicit desire to join the organization "to save his country from miseries" during an interview on his visit to Russia in November 2013. ${ }^{19}$ As a multilateral governmental organization whose member states boast a total population of nearly 2.9 billion and cover the majority of the Eurasian landmass, the SCO now has eight formal members (China, Russia, Kazakhstan, Kyrgyzstan, Tajikistan, Uzbekistan, Pakistan, and India), four observer members (Iran, Afghanistan, Mongolia and Belarus), and six dialogue partners (Sri Lanka, Turkey, Armenia, Azerbaijan, Cambodia, and Nepal). It represents a robust grouping of states of huge political, economic as well as military potential in the international arena.

Turkey was accepted as a dialogue partner in June 2012 as a win-win result for both the SCO and Turkey because, as an SCO expert comments, it "would show that even a close ally of the United States may be interested in projects out of Washington's control, and would involve Ankara into strategic and economic cooperation within the SCO framework." ${ }^{20}$ Although

19“Tuerqi zongli zai biaotai cheng zhuzhang jiaru shanghezuzhi, ciqian shengqing jiaru oumeng weiguo[Turkish PM Repeats Willingness to Join SCO, After Its Failure to Join EU]," Guanchazhe, November 24, 2013, http://www.guancha.cn/Third-World/2013_11_24_187876. shtml.

${ }^{20}$ Alexander Lukin, "The Shanghai Cooperation Organization: What Next?" Russia in Global Affairs, Vol. 5, No. 3 (July-September 2007), p. 155. 
Turkey will continue with efforts to join the EU in the foreseeable future, and its formal accession into the SCO remains an open question, more strategic cooperation between China and Turkey can be expected due to their growing mutual need.

\section{Future Trends of Sino-Turkish Relations}

How fast will future Sino-Turkish relations develop and what factors will influence the relationship? Based on the above analysis, the respective economic and political strength of both countries matters a lot, so do the changing dynamics of the global geopolitical environment. If both countries can maintain their economic growth at the current speed (China at 6 to 7 percent a year and Turkey at about 3 percent), they will definitely have a bigger say in the international arena, and their cooperation in economic as well as geopolitical fields is very likely to expand and generate lasting benefits to both.

As to the Xinjiang Uighur issue, although the Turkish government may continue adopting a sympathetic attitude toward the Uighurs under strong domestic pressure, it lacks the political will, economic capabilities or international support to take any substantive action to push forward a panTurkic program. On the contrary, to gain economic benefits and China's support on other strategic issues, Turkey is likely to work more closely with China on such programs as the "Belt and Road" Initiatives and the "Grand Development of West China," which will lead to growing prosperity of Xinjiang and ultimately help promote the Uighurs' identification with the Chinese central government.

In economic cooperation, with both countries taking strenuous efforts to upgrade their respective economic structure and China providing more preferential treatment to Turkish investment and businesses, closer economic ties between them will be developed, and their past trade imbalance is expected to lessen, not least because of the rapidly growing number of Chinese tourists to Turkey and their potential cooperation on investment in infrastructure projects along the New Silk Road.

In addition, as discussed above, China and Turkey will also likely expand their cooperation in security arenas and on multilateral platforms, especially if Turkey encounters even bigger obstacles on its 
way to joining the EU. However, given the loose ties between China and Turkey in modern history and the latter's strategic dependence on the West since the end of World War II, the future Sino-Turkish relationship will be largely determined by their respective relationships with the United States and the EU. 